\title{
EFFECTS OF ENDOPARASITISM OF Heteropneustes fossilis ON CONDITION FACTOR, GONAD AND BLOOD COMPOSITION OF HOST
}

\section{Sarker M. Ibrahim Khalil ${ }^{1}$, Kirtunia Juran Chandra² and David Rintu Das ${ }^{3^{*}}$}

${ }^{1}$ Department of Fish Health Management, Sylhet Agricultural University, Sylhet-3100 Bangladesh; ${ }^{2}$ Department of Aquaculture, Bangladesh Agricultural University, Mymensingh-2202, Bangladesh; ${ }^{3}$ Bangladesh Fisheries Research Institute, Freshwater Sub Station, Saidpur, Nilphamari, Bangladesh

*Corresponding author: David Rintu Das, E-mail: drd4272@yahoo.com

ARTICLE INFO

Received

12.10.2014

Accepted

17.12.2014

Online

27.12.2014

Key words:

Endoparasitism Heteropneutes fossilis

Gonad

Condition factor Blood parameter
ABSTRACT

Effects of endoparasitism of Heteropneustes fossilis on condition factor, gonad and blood composition of the host was conducted during July 2012 to June 2013. Fish samples were collected from various water bodies of Sylhet region. Total length, body weight, gonad weight and sex of hosts were recorded. Blood sample was collected from each fish. Six different species of parasites were identified from the hosts assessed as i). Euclinostomum multicaecum, ii) Allocreadium handiai, iii). Lytocestus indicus, iv). Pseudocaryophyllaeus heteropneustus, v). Procamallanus heteropneustus and vi). Paracamallanus equispiculus. Gonad weight, condition factors and blood parameters of $H$. fossilis were greatly affected with moderate infestations. The highest condition factor, 0.59 , was found in uninfested fish and lowest, 0.45 , in infested fish. Changes in the percent of haemoglobin and erythrocyte sedimentation rate (ESR) was also investigated. Percent loss of haemoglobin was 0.43 and erythrocyte sedimentation rate (ESR) was $5.19 \mathrm{~mm} / \mathrm{h}$. In general the health condition parameter due to effects of endoparasitism of the investigated fish was found negative impact for the culture production of the Singhi (Heteropneustes fossilis).

To cite this article: SMI Khalil, KJ Chandra and DR Das, 2014. Effects of endoparasitism of Heteropneustes fossilis on condition factor, gonad and blood composition of host. Res. Agric., Livest. Fish. 1(1): 159-167.

This article is an open access article licensed under the terms of the Creative Commons Attribution License.

www.agroaid-bd.org/ralf, e-mail: editor.ralf@gmail.com 


\section{INTRODUCTION}

Stinging catfish, popularly known as Singhi, Heteropneustes fossilis is an important fish in our country and getting increasingly popular showing a promising future for commercial culture (Barua, 1989). It has been contributed greatly as a delicious food fish of our country and esteemed as food for convalescence and invalids (Bhuiyan, 1964). However, once easily available in the nature, the fish has in the recent time, become scarce for many reasons including diseases and parasitic infestations (Kabata, 1985). Before starting a fish culture scheme everyone should be careful of problems, which threaten fish population and habitats. Among them effects of parasitic infestations resulting in diseases is the integral part of the existence of all animals including both cultured and wild fish population. Cross (1993) showed that normal growth of fishes is interrupted or inhibited if they are heavily infested with endoparasites.

Lots of research have been conducted on fish parasites in many countries of the world. Dias et al. (2006) studied on ecology of Clinostomum complanatum and recorded that the season, habitat and sex were not related to its prevalence. Hechinger et al. (2007) investigated the relationship between species richness and the abundance of larval trematodes. Mackiewicz (1982) stated that Clarias batrachus (Linn.) and $\mathrm{H}$. fossilis (Bloch) are the main hosts of caryophyllaeids in the Indian subcontinent. This group of cestodes are frequently found in these catfish in the intestine and stomach region of the host. In heavy infection of caryophyllaeid cestode, they can make obstruction in the intestine by mechanical means (Chandra, 1993). Unfortunately, very few works have been initiated on the effect of parasitism on the host animals particularly in freshwater fishes in Bangladesh. As $\mathrm{H}$. fossilis is a highly infested fish by different groups of parasites, their influence on this host is an essential task for determining its successful culture practice. Though a number of works on $H$. fossilis have been conducted in Bangladesh (Chandra and Khatun 1993, Chandra 1994, Chandra and Modak 1995, Chandra et al. 1996), effect of such parasitism on fish have not yet initiated except Laboni et al. (2012) in Clarias batrachus. The present research work was therefore conducted to know the effects on condition factor, gonad weight and blood parameters of $H$. fossilis due to parasitic infestations.

\section{MATERIALS AND METHODS}

A total of 210 Shingi, H. fossilis were collected during the period from July, 2012 to June, 2013. Live and fresh fishes were collected from Bandar market supplied from different haor named as Hakaluki haor, Tanguar haors etc. in Sylhet district. After collection, they were brought to the Disease Laboratory, Department of Fish Health Management, Sylhet Agricultural University, Sylhet by polythene bags or bucket with water in live condition for investigation. Before investigation the source, total length (TL), sex and weight of the fish were recorded in a data book. The host fish were also divided into 3 length groups $(12-16,17-21$ and 22-25 cm). A slit was made on ventral side near the genital pore on anal region and was opened towards the head up to the opercular region. After careful opening the stomach and the intestine were removed and put in a petridish containing water for parasitic investigation. After collection, the parasites were kept in normal saline for relaxation, flattened and fixed in F.A.A (Formaldehyde, Acetic acids, Alcohol). Some of the parasites were prepared for permanent slides.

For collecting blood, fish were caught gently in a small scoop net and transferred into a bowl containing the same water where they were acclimatized. After anesthetizing the fish with $5 \mathrm{ppm}$ quinaldine (Sigma chemical Co. USA) (Hossain and Shariff, 1992), blood samples were collected from the caudal vein with a sterile disposable plastic syringe coated with $3.6 \%$ sodium citrate as an anticoagulant according to Smith et al. (1952). To avoid contamination with mucus and water the area of insertion of syringe was wiped with alcohol cotton. Collected blood was gently pushed into 
a sterilized small glass vial containing anticoagulant, (potassium salt of ethylenediamine tetra-acetic acid, EDTA) to give a final concentration of $5 \mathrm{mg}$ EDTA per $\mathrm{cm}^{3}$ blood. This blood samples were used for determining the erythrocyte sedimentation rate (ESR), and haemoglobin concentration ( $\mathrm{Hb} \mathrm{g} \%)$.

\section{Data analysis}

\section{Gonad weight and Condition factor}

The total length $(\mathrm{cm})$ of each fish was taken from the tip of the lower jaw to the end of the lower lobe of the caudal fin. The body weight (g.) of each host were measured by electric balance. Condition factor was employed to evaluate the effect of parasite on the host. Condition factor was calculated by employing the formula $k=\frac{100 \times w}{l^{3}}$, Where $w=$ the weight of the fish in grams; $I=$ the length in centimeters. The magnitude of parasitism is indicated by the difference in $\mathrm{k}$ values of an infested and an uninfested fish. The gonad weight (g.) of infested and uninfested male and female were also measured by electric balance. Then the loss of gonad weight were measured by deducting the gonad weight of infested male and female from uninfested host.

\section{Haemoglobin Concentration}

Haemoglobin concentration was measured by the haematin method (Hesser, 1960). Sahli haemoglobinometer (Resistance LW, Germany) was used for determining the haemoglobin concentration. Prepared $0.1 \mathrm{~N}$ hydrochloric acid $(\mathrm{HCl})$ was placed up to the 20-marked graduation into the perfectly cleaned and dried haemoglobinometer tube. Blood sample was drawn into the Sahli pipette exactly up to $20 \mathrm{~cm}$ mark, side of the pipette was wiped with absorbent cotton and blood of the pipette was transferred immediately into specialized graduated tube for haemoglobin estimation containing $0.1 \mathrm{~N}$ $\mathrm{HCL}$ At that time pipette was rinsed 2 or 3 times by sticking water and the washings were added to the solution in the same tube. The tube was shaked until the blood was well mixed with the hydrochloric acid and water and the mixture became uniformly dark brown in colour. After about 5 min. water was added into the brown colour solution drop by drop with a dropper and each time the solution was mixed with a stirrer until the color of the solution matches the standard color of haemoglobinometer. After matching the result was taken in day light from the scale of the measuring tube by observing the graduation mark at the lower edge of the meniscus at the top of the liquid column and expressed in $g(\%)$.

\section{Erythrocyte Sedimentation Rate}

Collected blood with anticoagulant was inserted into dry wintrobe haematocrit tube by pasteur pipette exactly up to 0 or 100 mark according to Barnhart (1969). Care was taken not to allow any bubble in the tube. The tube was placed in a special rack in vertical position for $1 \mathrm{~h}$, the erythrocyte sedimentation rate (ESR) was calculated by measuring the distance the erythrocyte had sedimented from the scale at the top of the tube and the result was expressed in $\mathrm{mm} / \mathrm{h}$.

\section{RESULTS}

During the period of investigation six (6) species of parasites of different groups could be collected and identified shown in a separate communication (Khalil et al. 2013). These parasites are Euclinostomum multicaecum Tubangui and Masilungun, 1935; Allocreadium handiai Pandey, 1937; Lytocestus indicus Moghe, 1925; Pseudocaryophyllaeus heteropneustus Chandra and Khatun, 1993; Procamallanus heteropneustes Ali, 1957 and Paracamallanus equispiculus Sood, 1968. 


\section{Effects of parasitism}

\section{Changes in the nature of growth (Length)}

The experimental fishes were first differentiated as infested and uninfested and their average total length were presented in (Table 1) and their differences noted as 0.63 and the percentage loss of length was 3.39 .

Table 1. The average length (TL) of uninfested and infested $H$. fossils and the percentage of loss of length

\begin{tabular}{|cccccc|}
\hline SL. No. & $\begin{array}{c}\text { Infested or } \\
\text { uninfested }\end{array}$ & $\begin{array}{c}\text { Number } \\
\text { Examined }\end{array}$ & $\begin{array}{c}\text { Mean length } \\
\text { (cm) }\end{array}$ & $\begin{array}{c}\text { Loss of length } \\
\text { (cm) }\end{array}$ & $\begin{array}{c}\text { \% Loss of } \\
\text { length }\end{array}$ \\
\hline 1. & Uninfested & 92 & $18.61 \pm 2.17$ & - & - \\
2. & Infested & 118 & $17.98 \pm 2.21$ & 0.63 & 3.39 \\
\hline
\end{tabular}

\section{Changes in the nature of growth (Weight)}

During the period of investigation both the uninfested and infested host fish $\mathrm{H}$. fossilis were weighted. The average weight of the uninfested hosts were $33.02 \pm 10.53 \mathrm{~g}$ and the average weight of the infested hosts were $29.77 \pm 11.88 \mathrm{~g}$. Due to parasitic infestation the difference of weight was $3.25 \mathrm{~g}$ and the percentage loss of weight was 9.84 (Table 2). It appeared that there was a noticeable loss of weight of the host fish as a result of infestation of parasites after applying t-test at $5 \%$ level of significance.

Table 2. The average weight of uninfested and infested fish with the percentage loss of weight

\begin{tabular}{|lccccc|}
\hline $\begin{array}{l}\text { SL. } \\
\text { No. }\end{array}$ & $\begin{array}{c}\text { Infested or } \\
\text { Uninfested }\end{array}$ & $\begin{array}{c}\text { Number } \\
\text { Examined }\end{array}$ & $\begin{array}{c}\text { Mean weight } \\
(\mathbf{g})\end{array}$ & $\begin{array}{c}\text { Loss of weight } \\
\text { (g) }\end{array}$ & $\begin{array}{c}\text { \% Loss of } \\
\text { weight }\end{array}$ \\
\hline 1 & Uninfested & 92 & $33.02 \pm 10.53$ & - & - \\
2 & Infested & 118 & $29.77 \pm 11.88$ & 3.25 & 9.84 \\
\hline
\end{tabular}

\section{Changes in the nature of growth (Condition factor)}

During the study a total of $210 \mathrm{H}$. fossilis were examined where 92 fish were uninfested and 118 fish were infested with parasites. The condition factor of uninfested and infested fishes presented in Table 3 and it was cleared that the uninfested fish have higher condition factor (0.53) than infested ones (0.51). From this results it was indicated there was a marked differences after applying t-test at $5 \%$ level of significance.

Table 3. Condition factor of uninfested and infested with parasites in $H$. fossilis

\begin{tabular}{|lcc|}
\hline Infestation & Uninfested & Infested \\
\hline Mean length $(\mathrm{cm})$ & $18.61 \pm 2.17$ & $17.98 \pm 2.21$ \\
Mean weight $(\mathrm{g})$ & $33.02 \pm 10.53$ & $29.77 \pm 11.88$ \\
Condition factor & 0.53 & 0.51 \\
\hline
\end{tabular}

\section{Condition factor of uninfested and infested fish (H. fossilis) in different length Groups}

The highest condition factors $(0.65,0.62$ and 0.53$)$ were found in uninfested fish in small, medium and large length groups than infested ones $(0.62,0.55$ and 0.49$)$ (Table 4). From this results it was indicated that there was a marked difference among different length groups after applying t-test at 
$5 \%$ level of significance. So, it was indicated that there were significant differences among different level of infestation among different level of infestation after applying t-test at $5 \%$ level of significance.

\section{Changes in the nature of Gonad}

A total 210 hosts were examined where 96 were male and 114 were female. The average weight of gonad in uninfested and infested male were $0.93 \pm 0.19$ and $0.87 \pm 0.15$. The percentage loss of gonad weight was 6.45. The average weight of gonad in uninfested and infested female were $1.57 \pm 0.95$ and $1.50 \pm 0.71$. The percentage loss of gonad weight in female was 4.46 (Table 5).

Table 4. Relationship between infestation and the condition factor of fish parasite in different length groups in H. fossilis

\begin{tabular}{|lcccccc|}
\hline $\begin{array}{l}\text { Length } \\
\text { groups (cm) }\end{array}$ & \multicolumn{2}{c}{$12-16$} & \multicolumn{2}{c}{$17-21$} & \multicolumn{2}{c|}{ 22-25 } \\
\hline Infestation & Uninfested & Infested & Uninfested & Infested & Uninfested & Infested \\
\hline $\begin{array}{l}\text { Number of } \\
\text { fish }\end{array}$ & 33 & 47 & 42 & 54 & 17 & 17 \\
$\begin{array}{l}\text { Examined } \\
\text { Mean length } \\
(\mathrm{cm})\end{array}$ & $14.52 \pm 1.21$ & $14.41 \pm 1.01$ & $17.58 \pm 1.28$ & $18.25 \pm 1.18$ & $21.52 \pm 1.55$ & $21.44 \pm 0.56$ \\
$\begin{array}{l}\text { Mean weight } \\
(\mathrm{g})\end{array}$ & $19.75 \pm 4.21$ & $18.76 \pm 5.66$ & $33.92 \pm 6.93$ & $33.21 \pm 7.25$ & $52.53 \pm 11.15$ & $47.81 \pm 7.82$ \\
$\begin{array}{l}\text { Condition } \\
\text { factor }\end{array}$ & 0.65 & 0.62 & 0.62 & 0.55 & 0.53 & 0.49 \\
$\begin{array}{l}\text { Loss of } \\
\text { Condition } \\
\text { factor (\%) }\end{array}$ & - & 4.62 & - & 11.29 & - & 7.55 \\
\hline
\end{tabular}

Table 5. The average weight of gonad in infested and uninfested male and female

\begin{tabular}{|cccccc|}
\hline SL. No.: & Sex & $\begin{array}{c}\text { No. of examined } \\
\text { fish }\end{array}$ & $\begin{array}{c}\text { Average Gonad } \\
\text { weight of } \\
\text { Uninfested fish }\end{array}$ & $\begin{array}{c}\text { Average Gonad } \\
\text { weight of infested } \\
\text { fish }\end{array}$ & $\begin{array}{c}\text { \% Loss of } \\
\text { gonad } \\
\text { weight }\end{array}$ \\
\hline 01 & Male & 96 & $0.93 \pm 0.19$ & $0.87 \pm 0.15$ & 6.45 \\
02 & Female & 114 & $1.57 \pm 0.95$ & $1.50 \pm 0.71$ & 4.46 \\
\hline
\end{tabular}

\section{Changes in the nature of blood composition}

In this investigation it was observed that the hemoglobin content and Erythrocyte Sedimentation Rate (ESR) of uninfested and infested hosts. It was also observed in the percentage (\%) of loss of hemoglobin and Erythrocyte Sedimentation Rate (ESR) at different level of infestation of different length groups.

\section{Hemoglobin content in uninfested and infested $\boldsymbol{H}$. fossilis}

Total 210 hosts investigated to see the hemoglobin contents of $H$. fossilis. The range of hemoglobin percentage found in uninfested fishes was $2.8-6.2 \%$ and in infested it was found 2.2$6.2 \%$. The average percentage in uninfested fishes was $4.77 \pm 1.02$ and in infested was $4.18 \pm 0.71$. The loss of hemoglobin content was $0.59 \%$ (Table 6). From the above results it was indicated that there was significant differences among infested and uinfested hosts after applying t-test at $5 \%$ level of significance. 
Table 6. The hemoglobin content (\%) of uninfested and infested fish with the percentage loss of hemoglobin

\begin{tabular}{|lcccc|}
\hline SL. No. & $\begin{array}{c}\text { Infested or } \\
\text { uninfested }\end{array}$ & Number Examined & $\begin{array}{c}\text { Mean Hemoglobin } \\
\mathbf{( g / 1 0 0 m l )}\end{array}$ & $\begin{array}{c}\text { \% Loss of } \\
\text { Hemoglobin }\end{array}$ \\
\hline 1 & Uninfested & 92 & $4.77 \pm 1.02$ & - \\
2 & Infested & 118 & $4.18 \pm 0.71$ & 0.59 \\
\hline
\end{tabular}

The average Hemoglobin (\%), percentage loss of Hemoglobin in different level of infestation of parasites in $\boldsymbol{H}$. fossils

The highest (\%) loss of hemoglobin were 0.77 found in larger length group than others group. The lowest \% loss of hemoglobin were 0.35 found in medium length group. Overall differences in different infestation level of the host organism it was higher in high level of infestation in larger length group than others infection group (Table 7).

Table 7: The average Hemoglobin (\%), percentage loss of Hemoglobin in different level of infestation of parasites in $\mathrm{H}$. fossils

\begin{tabular}{|c|c|c|c|c|c|c|c|c|c|}
\hline $\begin{array}{l}\text { Length } \\
\text { groups } \\
\text { (cm) }\end{array}$ & & $12-16$ & & & $17-21$ & & & $22-25$ & \\
\hline Infestation & 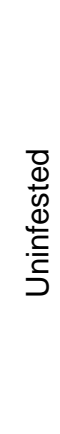 & 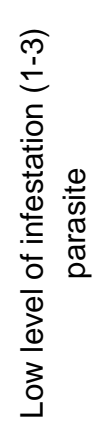 & 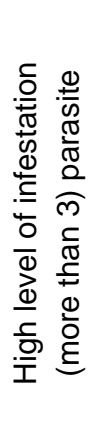 & 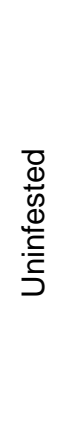 & 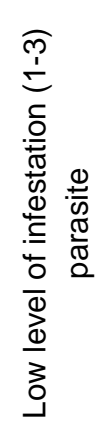 & 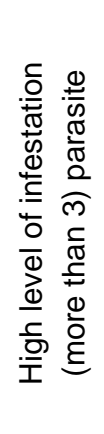 & 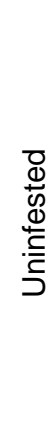 & 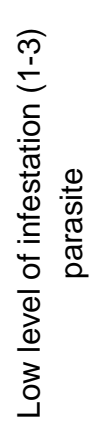 & 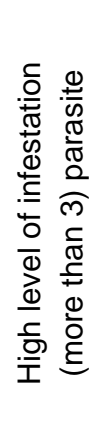 \\
\hline $\begin{array}{l}\text { Number } \\
\text { Examined }\end{array}$ & 33 & 39 & 8 & 42 & 39 & 15 & 17 & 12 & 5 \\
\hline $\begin{array}{l}\text { Average } \\
\text { Hemoglobin } \\
\text { (\%) }\end{array}$ & 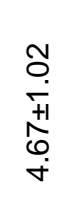 & $\begin{array}{l}0 \\
\ddot{0} \\
\dot{0} \\
+1 \\
\dot{+} \\
\dot{\forall}\end{array}$ & 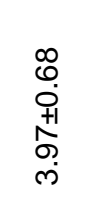 & $\begin{array}{l}m \\
\stackrel{M}{+} \\
+ \\
+1 \\
0 \\
0 \\
\dot{\sigma}\end{array}$ & 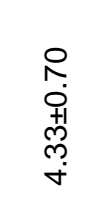 & $\begin{array}{l}\text { ơ } \\
\stackrel{\circ}{ } \\
\text { +1 } \\
\stackrel{\sim}{+}\end{array}$ & $\begin{array}{l}+ \\
\infty \\
0 \\
+1 \\
+1 \\
0 \\
\dot{+} \\
\dot{+}\end{array}$ & \begin{tabular}{l}
$\stackrel{+}{m}$ \\
0 \\
+ \\
+1 \\
\multirow{+}{*}{} \\
$\dot{\forall}$
\end{tabular} & $\begin{array}{l}\stackrel{N}{N} \\
\text { O } \\
\stackrel{+}{N} \\
\stackrel{+}{+}\end{array}$ \\
\hline $\begin{array}{l}\% \text { Loss of } \\
\text { Hemoglobin }\end{array}$ & ' & @̋ & $\begin{array}{l}0 \\
? \\
0\end{array}$ & & 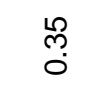 & $\stackrel{\infty}{+}$ & ' & 루 & $\begin{array}{c}\hat{N} \\
0\end{array}$ \\
\hline
\end{tabular}

\section{Erythrocyte Sedimentation Rate (ESR) in uninfested and infested $\boldsymbol{H}$. fossilis}

All fishes were examined to see the Erythrocyte Sedimentation Rate (ESR) of $H$. fossilis. The range of Erythrocyte Sedimentation Rate (ESR) percentage found in uninfested 1-6 mm/h and in infested it was found $1-6 \mathrm{~mm} / \mathrm{h}$. The average percentage in uninfested was $2.95 \pm 1.41 \mathrm{~mm} / \mathrm{h}$ and in infested was $2.78 \pm 1.29 \mathrm{~mm} / \mathrm{h}$. The loss of ESR was $5.76 \%$ (Table 8). 
Table 8. The ESR (\%) of uninfested and infested fish with the percentage loss of ESR

\begin{tabular}{|ccccc|}
\hline SL. No. & Infested or uninfested & Number Examined & Mean ESR $\mathbf{~ m m / h r}$ & \% Loss of ESR \\
\hline 01 & Uninfested & 92 & $2.95 \pm 1.41$ & - \\
02 & Infested & 118 & $2.78 \pm 1.29$ & 5.76 \\
\hline
\end{tabular}

ESR: Erythrocyte Sedimentation Rate

\section{DISCUSSION}

During the periods of investigation, six species of parasites $E$. multicaecum, $A$. handiai, $L$. indicus, $P$. heteropneustus, $P$. heteropneustus, and $P$. equispiculus were recorded from $H$. fossilis. These parasites were also reported by Ahmed et al. (1985), Sanaullah (1976), Mamnur Rashid et al. (1983) and Chandra and Khatun (1993) and Chandra (1994) from this host. So the present finding is the agreement of occurrence of these parasites in $H$. fossilis in Bangladesh waters specially from Sylhet region. However, Shahin et al. (2013) did not record caryophyllaeid parasites from $H$. fossilis in Mymensingh.

In the present investigation higher condition factor (0.53) recorded in uninfested fish than the average infested (0.51) ones. Das et al. (1997) described the mean values of condition factor and relative condition factor are 1.0755 and 1.0144 for catfish culture. When the values are in less than the mean values then the fishes fall in alarming situation due to parasitic infestation.

The highest loss of condition factor was found (11.29\%) in medium length group fish. The lowest loss of condition factor was (4.62\%) found in smaller length group. In $\mathrm{H}$. fossilis, the condition factor decreases when the number of parasite increases. Similar finding was observed by Mann (1953) and Kabata (1958) in case of attack of Lernaeocera. Almost identical observations were made by Sproston and Hartely (1941).

In the present investigation the haemoglobin concentration ranged from 1.0 to $6.0 \mathrm{~g} / 100 \mathrm{ml}$ of blood and average haemoglobin concentration of uninfested fish was $4.77 \pm 1.02 \mathrm{~g} / 100 \mathrm{ml}$ and $4.18 \pm 0.71 \mathrm{~g} / 100 \mathrm{ml}$ in infested hosts. The loss of haemoglobin percentage was 0.59 . By using acid haematin method Schiffman and Formm (1959) found a haemoglobin value of $6.5 \mathrm{~g} / 100 \mathrm{ml}$ of blood for rainbow trout S. gairdneri. Mulcahy (1970) gave a range of 5.6 to $15.00 \mathrm{~g} / \mathrm{ml}$ blood in pike determined through cyanmethaemoglobin method which is more or less similar to the present study.

Average erythrocyte sedimentation rate (ESR) of $\mathrm{H}$. fossilis was $2.95 \pm 1.41 \mathrm{~mm} / \mathrm{h}$ in uninfested fish and $2.78 \pm 1.29 \mathrm{~mm} / \mathrm{h}$ in infested fish. Here the loss of ESR was $5.76 \%$ which is nearer to the result of Siddiqui and Naseem (1979) where the ESR value of L. ruhita was $2.5 \pm 0.98 \mathrm{~mm} / \mathrm{h}$. Blaxhall and Daisley (1973) and McCarthy et al. (1973) reported the ESR value of rainbow trout to be $1-5 \mathrm{~mm} / \mathrm{h}$ and $1-8 \mathrm{~mm} / \mathrm{h}$ respectively. In this study ESR value ranged from 1.0 to $6.0 \mathrm{~mm} / \mathrm{h}$ in $\mathrm{H}$. fossilis which is within the above ranges. However different plasma viscosity and specific gravity of erythrocyte are responsible for different ESR values.

\section{REFERENCES}

1. Ahmad G and G J Srivastava, 1985. Histopathological alternation in the liver and skin of Heteropneustes fossilis exposed chronologically to a sublethal concentration of methylene blue. Pakistan Journal of Zoology, 17 (3): 239-246.

2. Ali, 1957. Procamallanus heteropneustes. Indian Journal of Helminthology, 8, p. 3.

3. Barnhart $R$ A, 1969. Effect of certain variables on haemetological characteristics of rainbow trout Salmo gairdneri (R.). Transactions of the American Fisheries Society, 98: 417-418. 
4. Barua G, 1989. The status of epizootic ulcerative syndrome of fish of Bangladesh. In: R.J. Roberts, B. Campbell and I.H. Macrae (eds) ODA Regional Seminar on epizootic ulcerative syndrome. Aquatic Animal Health Research Institute, Bangkok, pp. 13-20.

5. Bhuiyan AL, 1964. Fisheries of Dacca, Published by Asiatic Society of Pakistan, Dacca, $1^{\text {st }}$ ed. 148 pp.

6. Blaxhall PC and KW Daisley, 1973. Routine haematological methods for use with fish blood. Journal of Fish Biology, 5: 771-781.

7. Chandra KJ, 1993. Helminth parasites of certain freshwater and estuarine fishes of Bangladesh. Bangladesh Agricultural University Research Progress, 7: 643-654.

8. Chandra KJ and MR Khatun, 1993. A new species of caryophyllaeid cestode from Heteropneustes fossilis of Mymensingh. Rivista di Parassitologia, 10 (54): 235-239.

9. Chandra KJ, 1994. Infections, concurrent infections fecundity of Procamallanus heteropneustes Ali, parasitic to the fish Heteropneustes fossilis. Environment and Ecology, 12: 679-684.

10. Chandra KJ, NM Alam and MA Baki, 1996. Clinico-anatomical status on yellow grub disease of Singhi, Heteropneustes fossilis(Bloch) of Mymensingh. Bangladesh Journal of Agriculture, 21: 87-94

11. Chandra KJ and PC Modak, 1995. Activity, aging and penetration of the first stage larvae of Procamallanus heteropneustes Ali, 1957 (Nematode: Camallanidae). Asian Journal of Fisheries Science, 8: 95-101

12. Cross SX, 1993. Some host parasite relationship of the Trought lake region of Northern Wisconsis. Journal of Parasitology, $20: 132-133$.

13. Das NG, AA Majumder and S. M. M. Sarwar, 1997. Length-weight relationship and condition factor of catfish. Indian Journal of Fisheries, 44: 181-185.

14. Dias MLG, CV Mince-Vera, JC Eiras, MH Machado, GTT Souza and GC Pavnelli, 2006. Ecology of Clinostomum complanatum Rudolphi, 1814 (Trematoda : Clinostomidae) infecting fish from the floodplain of the high parna river, Brazil. Parasitological Research, 99(6): 675681.

15. Hesser EF, 1960. Methods for routine fish haematology. Progessive Fish Culture, 522: 164-171.

16. Heinchiger RP, KD Laffarty, TC Huspeni, AJ Brookes and AM Kuris, 2007. Relationship between species richness and abundance of larval trematodes and of local benthos and fishes. Ecology Heildelburg Germany, 151(1): 82-92.

17. Hossain MA and M Shariff, 1992. Effect of copper on humoral immune response in gold fish, Carassius auratus L. In: M. Shariff. R. Subasinghe and J. R. Arthur (eds.). Disease in Asian Aquaculture, Manila, Fish Health Section, Asian Fisheries Society, pp. 371-377.

18. Kabata Z, 1958. Lernaeocera obtusa n. sp. it biology and its effects on the haddock. Marine Research, 3: 1-26.

19. Kabata Z, 1985. Parasites and diseases of fish cultured in the tropics. Taylor and Francis Ltd. pp. 318.

20. Khalil SMI, KJ Chandra, MT Hasan, MA Kashem and DR Das, 2013. Parasitic infestations and their influence on length and weight of the host, Heteropneustes fossilis. Bangladesh Journal of Environmental Science, 24: 114-119.

21. Laboni NN, KJ Chandra and MS Chhanda, 2012. Effects of caryophyllaeid cestode infestations on Clarias batrachus (Linn.). Journal of Asiatic Society of Bangladesh, Science, 38 (2): 135-144.

22. Mackiewicz JS, 1982. Caryophyllidean (Cestoidea): Perspectives. Parasitology, 84: 397-417.

23. Moghe MA, 1925. A supplementary description of Lytocestus indicus Moghe, Cestoda. Parasit, 23: 84-87.

24. Mulcahy MF, 1970. Blood values in the pike Esox lucius L. Journal of Fish Biology, 2: 203-209.

25. Mamnur Rashid M, AKM Aminul Haque and KJ Chandra, 1983. Records of some metazoan parasites of Clarias batrachus (Linnaeus) from Mymensingh. Bangladesh Journal of Fisheries, 6: 3742.

26. Mann H, 1953. Lernaeocera branchialis (Copepoda Parasitica) and seine schadwirkung bei einigen Gadiden. Archa Fischereiwiss, 1952/53: 133-143.

27. McCarthy DH, JP Stevenson and MS Roberts, 1973. Some blood parameters of the rainbow trout (Saltno gairdneri, Richardson.). Journal of Fish Biology, 5: 1-8.

28. Pandey KC, 1937. Studies on Cestodes of India. III on a new species of Allocreadium handiai, 932 from Heteropneustes (Ham.). Indian Journal of Zoology, 4: 54-55. 
29. Sanaullah M, 1976. Contribution to the studies of some metazoan parasites in Heteropneustes fossilis (Bloch) and Clarias batrachus (Linnaeus) in Bangladesh. M. Sc. Thesis, Dept. of Zoology, University of Dhaka. pp. 116.

30. Schiffman RH and PO Fromm, 1959. Measurement of some physiological parameters in rainbow trout, Salmo gairdneri (P.). Cananadian Journal of Zoology, 37: 25-32.

31. Shahin MIH, KJ Chandra, DR Das and SMI Khalil 2013. Morphology and histopathology of alimentary canal of Clarias batrachus (Linnaeus) and Heteropneustes fossilis (Bloch). International Journal of Applied Life Sciences, 2(3): 11-20.

32. Smith GC, WM Lewis and HM Kaplan, 1952. A comparative morphologic and physiologic study of fish blood. Progressive Fish Culture,14: 169-172

33. Sood, 1968. Paracamallanus equispiculus. Indian Journal of Helminthology, 20(2). pp. 91.

34. Siddiqui $A Q$ and Naseem SM, 1979. The haematology of Rohu, Labeo rohita. Journal of Fisheries Biology, 14: 67-72.

35. Sproston NG and PHT Hartely, 1941. The ecology of some parasitic copepods of gadoids and othe fishes. Journal of Marine Biological Association, U.K., 25: 361-417.

36. Tubangui MA and F Masilungun, 1935. Caryophyllaeid parasites from $H$. fossilis of Philippine VI. Descriptions of new species and classification. Philippines Journal of Sciences, 51:167-174. 